\title{
GRAIN GROWTH AND MECHANICAL BEHAVIOUR OF POLAR ICE
}

\author{
by
}

\author{
P. Duval
}

Laboratoire de Glaciologie et Geophysique de l'Environnement, B.P. 96, 38402 - St Martin d'Heres Cedex, France

\begin{abstract}
Crystal size in polar ice caps increases with depth from the snow surface down to several hundred meters. Data on crystal growth in isothermal polar snow and ice show the same linear relationship between the size of crystals and their age. This paper reviews the mechanical behavior of polar ice which exhibits grain growth. Grain boundary migration associated with grain growth appears to be an efficient accomodation process for grain boundary sliding and dislocation glide. For grain growth to occur, strain energy must always be lower than the free energy of boundaries. The sintering of ice particles in polar firn is energized by the pressure due to the overburden of snow. Dislocation creep must be taken into account to explain the densification rate in the intermediate and final stage. Constants of power law creep should depend on the crystal growth rate.
\end{abstract}

\section{GRAIN GROWTH IN POLAR ICE}

The size of crystals in snow and ice in polar regions, as measured by the mean grain area on thin sections, increases with depth of burial. The growth rate of crystals has been measured at several locations in Antarctica and Greenland (Gow 1975; Gow and Williamson 1976; Narita and Maeno 1979; Duval and Lorius 1980; Alley and others 1982; Herron and Langway 1982).

At Byrd Station, grain growth seems to stop at 450 $m$ depth. At Camp Century, results suggest that grain growth stops at $400 \mathrm{~m}$ depth. At Vostok and Dome C, where the mean annual surface temperature is respectively -56 and $-54^{\circ} \mathrm{C}$, grain growth is observed at least down to $900 \mathrm{~m}$. However, a rapid decrease in grain size appears to be associated with the climatic Holocene-Wisconsin transition. In all cases grains remain equal-sized.

The time dependence of the growth rate of ice crystals is analogous to that observed in metallic and ceramic materials in that grain area $\left(l^{2}\right)$ increases linearly with time $t$ :

$$
l^{2}=l_{0}^{2}+\mathrm{Kt}
$$

The driving force for grain growth has been given by Hillert (1965). The driving force $F$ is positive for a grain size $l$ larger than the average grain size $l$ and negative otherwise, ie

$$
F=2 \gamma_{\mathrm{GB}}\left(\frac{1}{T}-\frac{1}{l}\right)
$$

where $\gamma_{\mathrm{GB}}$ is the grain boundary energy $\left(\approx 0.065 \mathrm{~J} / \mathrm{m}^{2}\right)$. The growth rate $K$ is expressed by:

$$
\mathrm{K}=\mathrm{K}_{0} \exp -\mathrm{Q} / \mathrm{RT}
$$

where $\mathrm{T}$ is the temperature, $\mathrm{R}$ is the gas constant and $\mathrm{Q}$ is the activation energy of the growth process. Figure 1 shows the variation of $\mathrm{K}$ with temperature in snow and in ice. The apparent activation energy obtained from the straight line (regression line) is $52 \mathrm{~kJ} / \mathrm{mole}$, which is slightly higher than the value given by Gow (1969) for

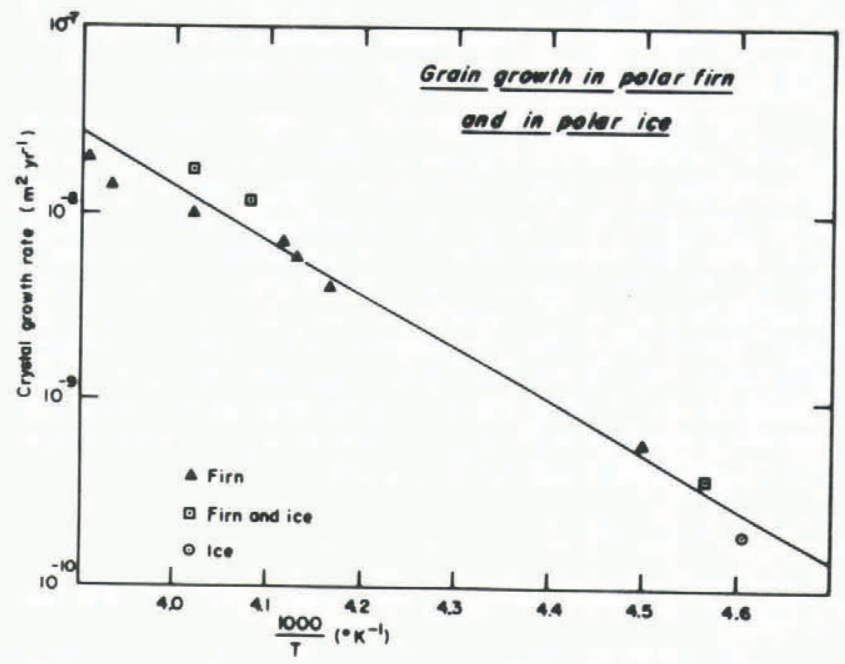

Fig.1. Temperature dependence of crystal growth rate in polar ice.

snow (48.6 $\mathrm{kJ} / \mathrm{mole})$. Equation 1 is observed to describe grain growth only if the drag force from pores is not significant. Examination of thin sections of firn reveals that pores remain on grain boundaries during grain growth. This means that pores must migrate along with boundaries. Since the crystal growth rate takes the same value in firn and in ice, the restraint on boundary movement by pores does not appear to be important. This can only be the case if pore mobility is much greater than boundary mobility.

Below the firn-ice transition, bubbles show no tendency to migrate to grain boundaries during grain growth (Gow 1968a). Separation of pores from the boundary occurs when the drag force due to pores, which is proportional to the pore size and the number of pores per unit grain boundary area, is small compared with the driving force for grain growth. For Byrd Station, the mean diameter of air bubbles is about $0.95 \mathrm{~mm}$ at the pore close-off depth whereas the crystal size is about $2 \mathrm{~mm}$ (Gow 1968a). Since, at this depth, there are as many crystals as bubbles (Gow 1968a), the drag force of pores is weak.

\section{DEFORMATION MECHANISMS OF POLAR ICE AT SHALLOW DEPTH}

In the first hundred meters of polar ice caps deviatoric stresses are smaller than $0.1 \mathrm{MPa}$ and strain rates lower than $10^{-11} \mathrm{~s}^{-1}$. From the deformation map given by Duval and others (1983) the expected deformation mechanisms are diffusional creep and power law creep. At Byrd Station, the compressive vertical strain rate is about $2.5 \times 10^{-12} \mathrm{~s}^{-1}$ (Whillans and Johnsen 1983), which gives a deviatoric stress $\delta_{2}^{\prime}=0.088 \mathrm{MPa}$ for diffusional creep and $\delta_{\mathrm{zz}}^{\prime}=0.053 \mathrm{MPa}$ for power law creep (Duval and Lliboutry, 1985). Dislocation creep would therefore be the dominant flow mechanism for the Byrd ice cores from the surface. But Duval and Lliboutry (1985) assumed that the continuous boundary 
migration was a much more efficient process for the accomodation of grain boundary sliding than the diffusional flow. On the other hand, Equation 1 implies that strain energy is small in comparison with the grain boundary energy which drives grain growth. The stored energy for dislocation creep increases with strain and can be higher than $10^{4} \mathrm{~J} / \mathrm{m}^{3}$ after a strain of $1 \%$ (Duval and others 1983). Since the driving force $F$ (Equation 2) is typically of order $100 \mathrm{~J} / \mathrm{m}^{3}$, power law creep is not compatible with grain growth.

Analysis of the inclinometer survey of the Byrd borehole by Lliboutry and Duval (1985) shows that the Newtonian viscosity of the ice is three to four orders of magnitude lower than theory of diffusional creep predicts. Results from Camp Century (Greenland) confirm those at Byrd Station (Paterson 1983). But, Paterson gives a value of flow parameter $A$ of the power law creep $\left(\dot{\epsilon}=A T^{\mathrm{n}}\right)$ for Holocene ice fifteen to twenty times greater than that expected from laboratory tests. A good fit of data from both stations is found with a flow model with $\mathrm{n}=3$.

As concerns the dislocation glide, grain growth should impede strain-hardening. The stored energy from dislocations near grain boundaries could be lower than that necessary to initiate recrystallization $\left(\cong 10^{4} \mathrm{~J} / \mathrm{m}^{3}\right)$ and than the driving force for grain growth $\left(100 \mathrm{~J} / \mathrm{m}^{3}\right)$. If $\rho_{g}$ is the density of dislocations near grain boundaries, $\rho_{\mathrm{g}} \mathrm{K} / l^{2}$ dislocations per unit area and per unit time will be annihilated by grain boundary migration. In order for grain growth to occur, the accumulation of dislocations against boundaries must not exceed a critical value $\rho_{\mathrm{gc}}$. A density $\rho_{\mathrm{gc}}$ of dislocations has an associated energy of roughly:

$$
\mathrm{E} \cong \rho_{\mathrm{gc}} \mathrm{Gb}^{2} / 2
$$

where $G$ is the shear modulus and $b$ is the Burgers vector.

By assuming that $E=10 \mathrm{~J} / \mathrm{m}^{3}$ we have a critical dislocation density of about $10^{10} / \mathrm{m}^{2}$.

In conclusion, grain boundary migration associated with grain growth in polar ice may be an efficient accomodation process for grain boundary sliding and for dislocation glide.

\section{PRESSURE SINTERING OF POLAR ICE}

\section{Stages of snow densification}

The densification of polar snow is generally divided into three stages. In the first stage (density $\rho<0.55 \mathrm{~g} \mathrm{~cm}^{-3}$ ), densification is dominated by grain packing. Mechanisms such as evaporation-condensation contribute to sintering in the presence of temperature gradients (Gow 1975). Rapid grain growth in the top 10 $\mathrm{m}$ of snow must also be taken into account. This stage is not analysed in this paper.

During the second stage $(\rho<\rho$, the pore close-of $f$ density) densification is determined by the ice deformation near the contact regions of grains.

In the final stage the increase in the ice density beyond $\rho_{c}$ is attributed to bubble compression, and densification is determined by the creep of ice surrounding bubbles. By analysing several physical properties of firn such as the air permeability, Maeno and others (1978) have proposed a critical density of $0.73 \mathrm{~g} \mathrm{~cm}^{-3}$. At this density air bubbles are concentrated at intersections of grain boundaries and the further densification results in the splitting of air channels (Narita and others 1978).

\section{Mechanisms of densification}

Several physical mechanisms may operate during the densification process: particle rearrangement, diffusion, and dislocation creep. The sintering of firn is driven by capillary forces and specially by the pressure due to the overburden snow. Figure 2 gives the relationship between the snow density and the snow load pressure at Byrd Station. At the pore close-off the snow load pressure is $0.419 \mathrm{MPa}$ compared with deviatoric stresses for the flow of ice sheets lower than $0.1 \mathrm{MPa}$ (Gow 1968a). In the second stage the effective pressure

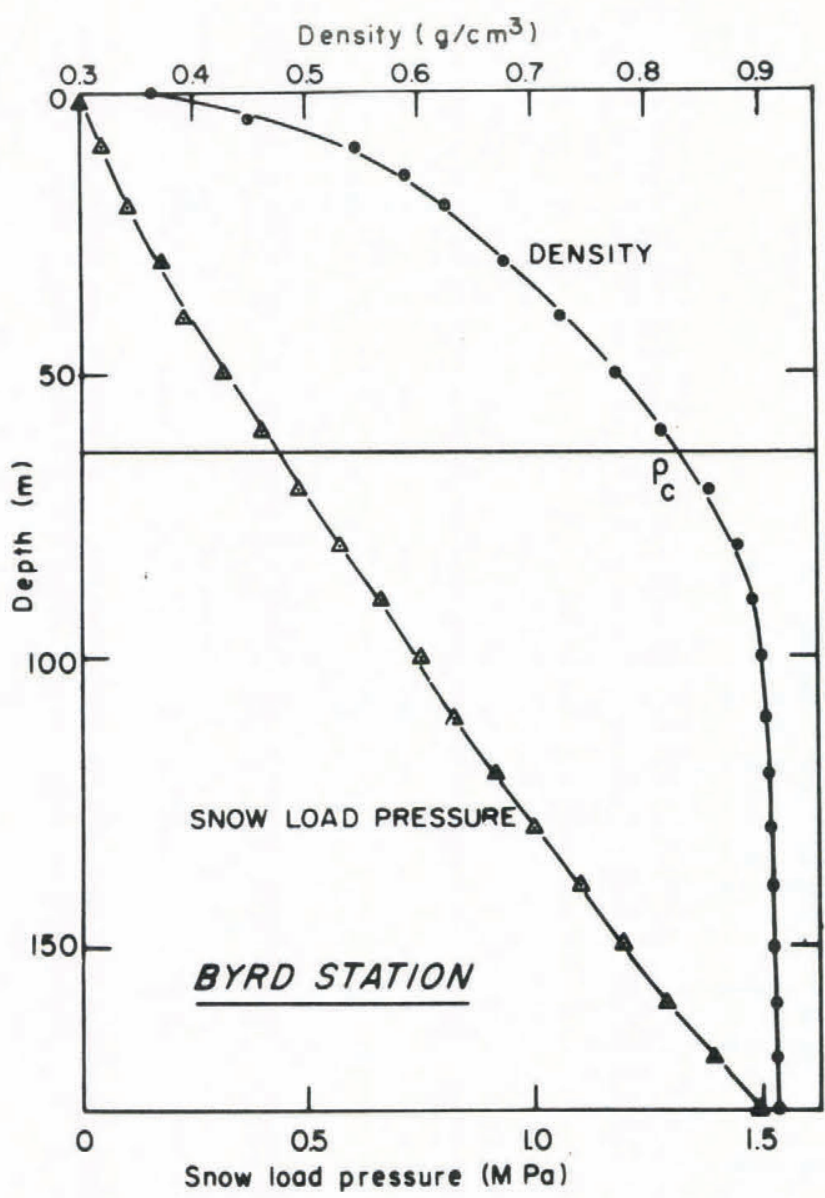

Fig.2. Density and snow load pressure versus depth at Byrd Station $\left(80^{\circ} 01^{\prime} \mathrm{S}, 119^{\circ} 32^{\prime} \mathrm{W}\right.$; mean annual temperature $-28^{\circ} \mathrm{C}$; accumulation rate: $\left.15.7 \mathrm{~g} \mathrm{~cm}^{-2} \mathrm{year}^{-1}\right)$. $\rho_{\mathrm{c}}$ is the pore close-off density. Data are from Gow (1968b).

acting on a particle contact is higher than the load pressure (Arzt and others 1983). Therefore, the expected dominant mechanism of densification should be power law creep. The complete treatment of the power law creep model was given by Wilkinson and Ashby (1975). The laws for densification relate the densification rate $\dot{\rho}$ to the load pressure and to the value of the density $\rho$. In the final stage, pores are considered as spherical holes and densification is determined by the creep of ice surrounding each pore. In the intermediate stage $\left(\rho_{c}>p>0.55 \mathrm{~g} \mathrm{~cm}^{3}\right)$ pores are considered as a network of cylindrical holes.

The rate of densification is expressed by:

$$
\dot{\rho} / \rho=\frac{2 \mathrm{~A}(1-\rho / \rho \mathrm{i})}{\left[1-(1-\rho / \rho \mathrm{i})^{1 / \mathrm{n}}\right] \mathrm{n}} \quad(2 \mathrm{P} / \mathrm{n})^{\mathrm{n}}
$$

for cylindrical pores, and

$$
\dot{\mathrm{\rho}} / \mathrm{\rho}=3 \mathrm{~A} / 2 \frac{(1-\mathrm{\rho} / \mathrm{\rho i})}{\left[1-(1-\rho / \rho \mathrm{i})^{1 / \mathrm{n}}\right] \mathrm{n}}\left[3 / 2 \mathrm{n}\left(\mathrm{P}-\mathrm{P}_{\mathrm{i}}\right)\right]^{\mathrm{n}}
$$

for spherical pores, where $P$ is the load pressure, $P_{i}$ is the bubble pressure, $A$ and $n$ are constants of the power law creep, and $p_{i}$ is the density of bubble free ice.

Figure 3 shows the variations of the rate of densification and of the effective pressure with density at Byrd Station. Density data are after Gow (1968b). The effective pressure was calculated with the pore close-off density $\rho_{c}=0.825 \mathrm{~g} \mathrm{~cm}^{-3}$ and $\rho_{i}=0.9204 \mathrm{~g}$ $\mathrm{cm}^{-3}$ as suggested by Gow (1968a). The rate of densification decreases by a factor higher than 3 within 


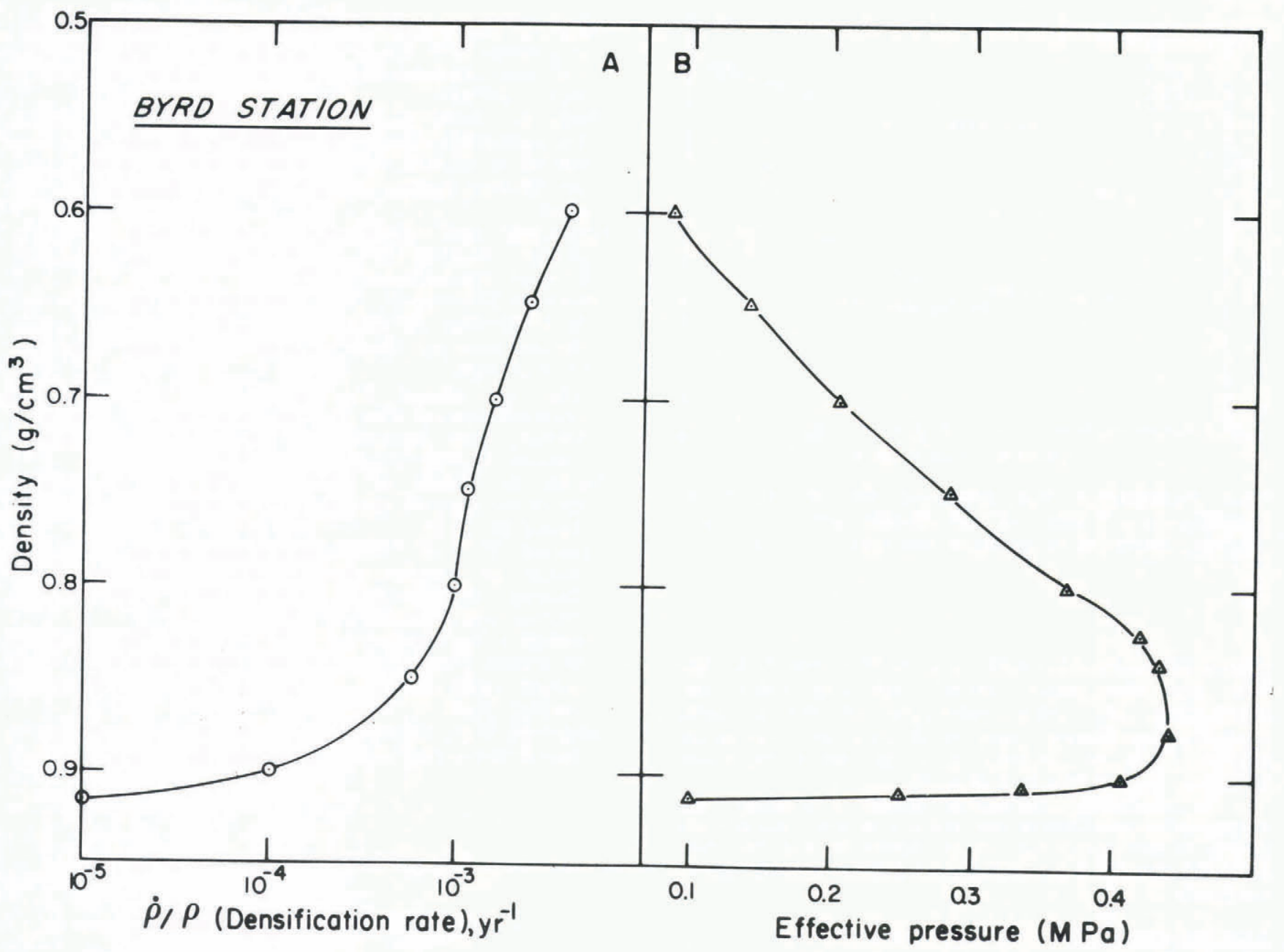

Fig.3. Densification data for ice at Byrd Station. A) Densification rate versus density B) Effective

the intermediate stage in spite of the important increase in the effective pressure. But, as suggested by Equations 5 and $6, \dot{\rho} / \rho$ decreases with density for a constant effective pressure.

The densification rate can be corrected for the effect of density by dividing by $f(\rho)$, where

$$
f(\rho)=\frac{(1-\rho / \rho i)}{\left[1-(1-\rho / \rho \mathrm{i})^{1 / n}\right] \mathrm{n}}
$$

The adjusted $\dot{\rho} / \rho / f(p)$ versus the effective pressure curves are plotted in Figure 4 (see Table 1) with $n=3$.
The rate of densification increases with stress, but the power law creep model does not seem verified.

\section{DISCUSSION}

Results given in Figure 4 show that the densification models constructed by Wilkinson and Ashby (1975) cannot be applied to polar snow just as they are. As shown by Maeno (1982) and by Arzt and others (1983), diffusional creep is not an efficient mechanism of densification for the intermediate stage and for the major portion of the final stage. Several factors which have not been taken into account can influence the densification rate (Maeno and Ebinuma 1983). The most important is probably grain growth. Since the crystal

TABLE 1. EXPERIMENTAL DATA FOR POLAR ICE AT BYRD STATION.

\begin{tabular}{|c|c|c|c|c|c|c|c|c|}
\hline $\begin{array}{l}\text { Depth } \\
\text { (m) }\end{array}$ & $\begin{array}{l}\text { Age } \\
(y r)\end{array}$ & $\begin{array}{c}\rho \\
\left(\mathrm{g} \mathrm{cm}^{-3}\right)\end{array}$ & $\begin{array}{c}\dot{\rho} / \rho \\
\left(\mathrm{yr}^{-1}\right)\end{array}$ & $f(p)$ & $\begin{array}{c}\dot{\rho} / \rho / f(p) \\
\left(y r^{-1}\right)\end{array}$ & $\begin{array}{l}\text { Load } \\
\text { pressure } \\
(\mathrm{MPa})\end{array}$ & $\begin{array}{l}\text { Effective } \\
\text { pressure } \\
(\mathrm{MPa})\end{array}$ & $\begin{array}{l}\text { Crystal } \\
\text { size } \\
\left(\mathrm{m}^{2}\right)\end{array}$ \\
\hline $\begin{array}{r}17 \\
26 \\
35 \\
45 \\
57 \\
65 \\
75 \\
100 \\
128 \\
171\end{array}$ & $\begin{array}{r}60 \\
86 \\
122 \\
175 \\
236 \\
277 \\
332 \\
469 \\
634 \\
855\end{array}$ & $\begin{array}{l}0.6 \\
0.65 \\
0.7 \\
0.75 \\
0.8 \\
0.8425 \\
0.87 \\
0.90 \\
0.91 \\
0.914\end{array}$ & $\begin{array}{rrr}3.9 \times 1 & 10^{-3} \\
2.5 & \times 10^{-3} \\
1.6 \times & \times 10^{-3} \\
1.17 \times & 10^{-3} \\
1 \times & \times 10^{-3} \\
1 & \times & 10^{-3} \\
4.5 & \times 10^{-4} \\
1.1 & \times 10^{-4} \\
3.9 & \times 10^{-5} \\
9 & \times & 10^{-6}\end{array}$ & $\begin{array}{l}13 \\
7.8 \\
4.4 \\
2.39 \\
1.1 \\
0.479 \\
0.229 \\
0.05 \\
0.023 \\
0.013\end{array}$ & $\begin{array}{l}3 \times 10^{-4} \\
3.2 \times 10^{-4} \\
3.6 \times 10^{-4} \\
4.9 \times 10^{-4} \\
9.1 \times 10^{-4} \\
2 \times 10^{-3} \\
1.96 \times 10^{-3} \\
2.2 \times 10^{-3} \\
1.69 \times 10^{-3} \\
6.9 \times 10^{-4}\end{array}$ & $\begin{array}{l}0.094 \\
0.135 \\
0.192 \\
0.275 \\
0.370 \\
0.435 \\
0.521 \\
0.736 \\
0.995 \\
1.34\end{array}$ & $\begin{array}{l}0.094 \\
0.135 \\
0.192 \\
0.275 \\
0.37 \\
0.42 \\
0.44 \\
0.4 \\
0.24 \\
0.1\end{array}$ & $\begin{array}{l}1.0 \times 10^{-6} \\
1.6 \times 10^{-6} \\
3.0 \times 10^{-6} \\
4.1 \times 10^{-6}\end{array}$ \\
\hline
\end{tabular}




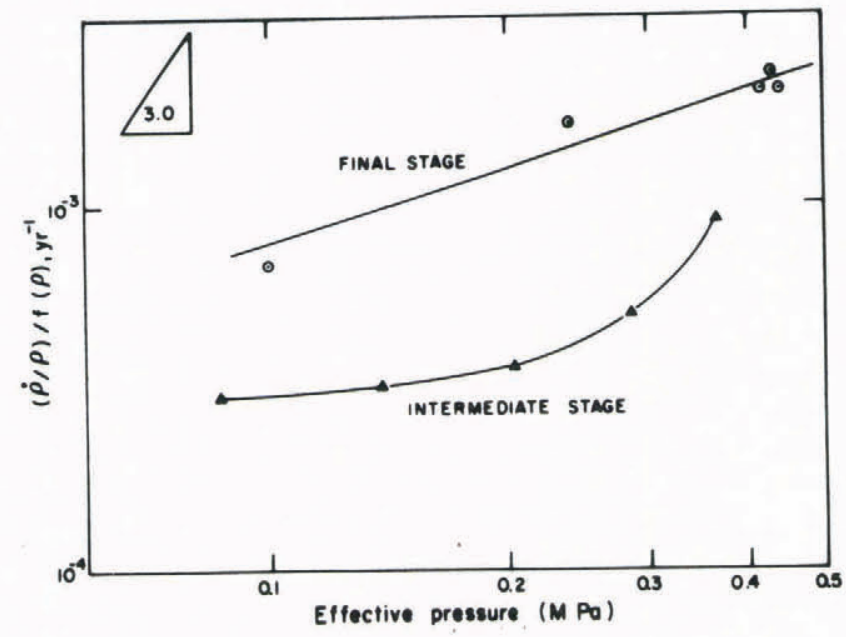

Fig.4. Densification rate normalized for the effect of porosity as a function of the effective pressure at Byrd Station. Power law creep model was applied with $\mathrm{n}=3$.

growth rate takes the same value in firn and in bubble free ice, the strain energy resulting from the deformation near grain boundaries by the effective pressure must belower than the driving force for grain growth. This is possible only if grain boundary migration impedes strain hardening

In conclusion, dislocation creep is probably the densification mechanism for polar ice; but constants A and $\mathrm{n}$ in the power law creep cannot be derived from the minimum creep rate obtained after a deformation of about $1 \%$.

\section{REFERENCES}

Alley R B, Bolzan J F, Whillans I M 1982 Polarfirn densification and grain growth. Annals of Glaciology 3: $7-11$

Arzt E, Ashby M F, Easterling K E 1983 Practica applications of hot-isostatic pressing diagrams: four case studies. Metallurgical Transactions 14 A(2): 211-221

Duval P, Lorius C 1980 Crystal size and climatic record down to the last ice age from Antarctic ice. Earth and Planetary Science Letters 48: 59-64

Duval P, Ashby M F, Anderman I 1983 Ratecontrolling processes in the creep of polycrystalline ice. Journal of Physical Chemistry 87: 4066-4074

Duval P, Lliboutry L (1985). Superplasticity owing to grain growth in polar ices. Journal of Glaciology 31(107): $60-62$

Gow A J 1968a Bubbles and bubble pressures in Antarctic glacier ice. Journal of Glaciology 7(50): $167-182$

Gow A J 1968b Deepcore studies of the accumulation and densification of snow at Byrd Station and Little America, Antarctica. CCREL Research Report 197: 1-49

Gow A J 1969 On the rates of growth of grains and crystals in South Polar firn. Journal of Glaciology 8(53): $241-252$

Gow A J 1975 Time-temperature dependence of sintering in perennial isothermal snowpacks. IAHS Publication 114 (Symposium of Grindelwald, Switzerland, 1974, Snow mechanics): $25-41$

Gow A J, Williamson T C 1976 Rheologicalimplications of the internal structure and crystal fabrics of the West Antarctic ice sheet as revealed by deep core drilling at Byrd Station. CRREL Report 76-35

Herron S L, Langway C C 1982 A comparison of ice fabrics and textures at Camp Century, Greenland and Byrd Station, Antarctica. Annals of Glaciology 3: $118-124$

Hillert M 1965 Onthe theory of normal and abnormal grain growth. Acta Metallurgica 13: 227-238
Lliboutry L, Duval P (1985) Various isotropic and anisotropic ices found in glaciers and polar ice caps and their corresponding rheologies. Annales Geophysicae 3(2): $\quad 207-224$

Maeno N, Narita H, Araoka K 1978 Measurements of air permeability and elastic modulus of snow and firn drilled at Mizuho Station, East Antarctica. Memoirs of the National Institute of Polar Research, Special Issue 10: 62-76

Maeno N 1982 Densification rates of snow at polar glaciers. Memoirs of the National Institute of Polar Research, Special Issue 24: 204-211

Maeno N, Ebinuma T 1983 Pressuresintering of ice and its implication to the densification of snow at polar glaciers and ice sheets. Journal of Physical Chemistry 87: $4103-4110$

Narita H, Maeno N, Nakawo M 1978 Structural characteristics of $\mathrm{firn}$ and ice cores drilled at Mizuho Station, East Antarctica. Memoirs of the National Institute of Polar Research, Special Issue 24: 48-61

Narita H, Maeno N 1979 Growth rates of crystal grains in snow at Mizuho Station, Antarctica. Antarctic Record 67: 11-17

Paterson W S B 1983 Deformation within polar ice sheets: an analysis of the Byrd station and Camp Century borehole-tilting measurements. Cold Regions Science and Technology 8: 165-179

Whillans I M, Johnsen S J 1983 Longitudinal variations in glacial flow; theory and test using data from Byrd station strain network, Antarctica. Journal of Glaciology 29(101): 78-97

Wilkinson D S, Ashby M F 1975 Pressure sintering by power law creep. Acta Metallurgica 23(11): 1277-1285 